Рекомендована д. фрармац. наук, профр. А. С. Немченко

УДК 671.1

DOI 10.11603/2312-0967.2016.4.7119

\title{
МЕТОДОЛОГІЯ ОПЛАТИ ПРАЦІ В ДЕРЖАВНИХ ЗАКЛАДАХ ОХОРОНИ ЗДОРОВ'Я
}

\author{
() А. В. Комар, А. М. Кричковська, Н. Л. Заярнюк, А. І. Хоменко, В. П. Новіков \\ Національний університет «Львівська Політехніка», Львів
}

\begin{abstract}
Резюме: досліджено основні аспекти організації обліку видатків на оплату праці в державних закладах охорони здоров'я на підставі діючого нормативно-правового забезпечення. Розглянуто організацію обліку видатків медичного закладу на основну, додаткову зарплату та інші компенсаційні, заохочувальні виплати в системі рахунків бюджетного обліку.
\end{abstract}

Ключові слова: фронд оплати праці, касові та фрактичні видатки, видатки на оплату праці, основна та додаткова зарплата, компенсаційні та заохочувальні виплати.

Вступ. Головною кошторисною статтею видатків державних закладів охорони здоров'я (303) є оплата праці. На її реалізацію виділяються кошти із загального і спеціального фондів медичного закладу. В організаційній структурі державних 303 передбачено фрункціонування закритого (інколи відкритого) типу аптечного закладу (фрармацевтичного відділення), оплата працівників якого здійснюється за прийнятою методологією. В роботі бухгалтерії кожного 303 особливе місце займають питання видатків на оплату праці. 3 одного боку, це зумовлено ставленням до даного питання самих медичних та фрармацевтичних працівників, для яких заробітна плата $€$ джерелом матеріальних благ. 3 іншого боку, кошти, які спрямовані 303 на оплату праці, виділяються з бюджету держави (місцевого бюджету), мають цільове призначення і не можуть бути використані на інші потреби закладу, відповідно до затвердженого кошторису доходів і видатків.

Актуальність дослідження полягає в тому, що дана стаття $€$ першим етапом на шляху дослідження системи оплати праці в умовах роботи державної медичної галузі та її фрармацевтичної складової за системою М. О. Семашко. Дана публікація є практичним підведенням підсумків та предметом аналізу системи оплати праці медичних та фрармацевтичних працівників у рамках діяльності сучасної медичної галузі часів незалежної України взірця 2016 року.

Зацікавлення обліковими аспектами праці та її оплати у державних 303 знайшло своє відображення у працях вітчизняних вчених-економістів, серед яких: П. Й. Атамас, П. Т. Ворончук, Р. Т. Джога, Е. П. Дедков, С. Я. Зубілевич, М. М. Каленський, Є. В. Калюга, Л. М. Кіндрацька, І. О. Кондратюка, В. І. Крисюк, С. О. Левицька, Т. П. Остапчук, Н. А. Остап'юк, С. В. Свірко, Н. І. Сушко, О. І. Шуляк, І. Д. Фаріон, О. В. Юрченко та ін. Аналітика наукового доробку вітчизняних вчених, свідчить про вагомість та прак- тичну цінність отриманих результатів у сфері обліку. Втім постійні зміни у законодавчих актах України, перспективи запровадження у вітчизняну практику національних положень (стандартів) бухгалтерського обліку в державному секторі викликають об'єктивну необхідність поглиблення теоретичних досліджень і методологічних розробок, спрямованих на вдосконалення практики бухгалтерського обліку видатків на оплату праці у державних 303.

Згідно з Постановою КМУ від 01.01.2017 р. у законну силу вступає законопроект за № 2309а від 07.07.2015 р. «Проект Закону про внесення змін до деяких законодавчих актів України щодо удосконалення законодавства з питань охорони здоров'я», який призведе до зміни системи фрінансування медичної галузі в цілому, а, відповідно, й оплати праці срахівців медичних та аптечних закладів охорони здоров'я. Саме тому метою даної статті було комплексне дослідження теоретичних та організаційноправових засад обліку видатків на оплату праці в державних 303. Окреслена мета дослідження зумовила постановку та вирішення таких завдань: дослідити економічні та організаційні засади оплати праці в 303, джерела ії фрінансування; ознайомитись 3 основними нормативно-правовими аспектами обліку видатків на оплату праці в 303; розглянути особливості організації обліку касових і фактичних видатків на оплату праці медичного закладу або аптечного підприємства в системі бухгалтерських рахунків та реєстрів синтетичного й аналітичного обліку тощо.

Методи дослідження. Використовували метааналіз законодавчих нормативно-правових актів, що регулюють оплату праці в державних закладах охорони здоров'я та фрармацевтичних закладах, статистичний аналіз.

Результати й обговорення. Видатки на заробітну плату є захищеною статтею бюджету і мають найбільшу питому вагу в складі поточних видатків державно-

ISSN 2312-0967. Фармацевтичний часопис. 2016. № 4 
го 303 та аптеки. Поділ видатків фонду оплати праці в державних 303 наведено на рисунку 1. Видатки 303, що здійснюються за рахунок коштів державного або місцевого бюджетів, називаються видатками загального фонду. Видатки, здійснені за рахунок позабюджетних надходжень, називаються видатками спеціального фронду [1]. 3 метою упорядкування умов оплати праці працівників 303 і установ соціального захисту населення та на виконання Постанови Кабінету Міністрів України від 30.08.2002 р. № 1298 «Про оплату праці працівників на основі Єдиної тарифної сітки розрядів і коефіцієнтів з оплати праці працівників установ, закладів та організацій окремих галузей бюджетної сорери» затверджено наказ Міністерства праці та соціальної політики України, Міністерства охорони здоров'я України «Про впорядкування умов оплати праці працівників 303 та установ соціального захисту населення» від 05.10.2005 р. № 308/519 $[8,9]$. Вищезгаданим наказом затверджено умови оплати праці працівників 303 та установ соціального захисту населення на основі Єдиної тарифної сітки розрядів і коефіцієнтів 3 оплати праці працівників установ, закладів та організацій окремих галузей бюджетної сорери; установлено посадові оклади (тарифнні ставки), доплати та надбавки керівникам 303 та установ соціального захисту населення в межах фонду заробітної плати [8].

Для оцінки розміру заробітної плати працівників, а відтак видатків 303 на оплату праці, застосовують показник фонду оплати праці. До фронду оплати праці належать нарахування працівникам у грошовій та натуральній формах (оцінені у грошовому вираженні) за відпрацьований та невідпрацьований час, який підлягає оплаті, або за виконану роботу незалежно від джерела фрінансування цих виплат [5]. Фонд оплати праці розраховують відповідно до Інструкції зі статистики заробітної плати, затвердженої наказом Держкомстату України від 13.01.2004 р. № 5. Інструкція містить основні методологічні положення щодо визначення показників оплати праці у фрормах державних статистичних спостережень для одержання об'єктивної статистичної інфрормації про розміри та структуру заробітної плати найманих працівників. Цим документом також визначено порядок розрахунку статистичних показників середньої заробітної плати, які $є$ важливими індикаторами соціально-економічного розвитку [7].

Фонд оплати праці 303 складається 3 трьох груп нарахувань - це основної, додаткової заробітної плати та інших заохочувальних і компенсаційних виплат (рис. 2).

Основну заробітну плату працівників 303 встановлюють у вигляді посадових окладів (тарифних ставок). Визначені згідно з Умовами оплати праці працівників 303 та установ соціального захисту населення посадові оклади (тариснні ставки) є державними гарантіями мінімальних рівнів оплати праці для конкретних профресійно-кваліфікаційних груп працівників, які перебувають у трудових відносинах із 303 та установами соціального захисту населення всіх форм власності, при додержанні встановленої законодавством про працю тривалості робочого часу та виконанні працівником посадових обов'язків (норм праці) [8]. Величина посадових окладів (тарифних ставок) визначається за тарифними розрядами Єдиної тарифної сітки, які встановлюються профресіоналам, фрахівцям залежно від наявної кваліфікаційної категорії, робітникам - кваліфікаційного розряду у межах діапазону, визначеного для цих посад (професій) Довідником кваліфікаційних характеристик професій працівників (№0336203-04) і відображаються у тарифікаційному списку [9]. Зростання посадових

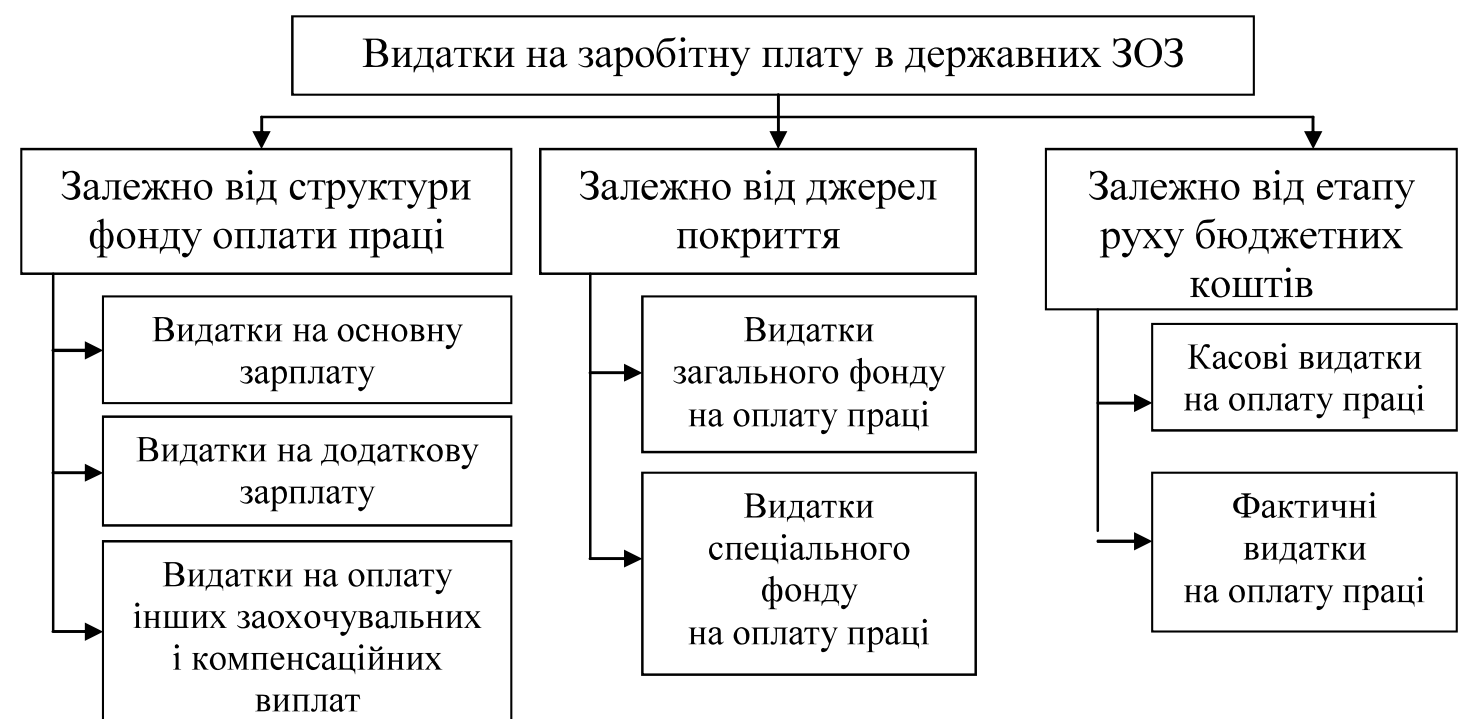

Рис. 1. Класифрікація видатків на оплату праці в державних 303 (власне опрацювання).

ISSN 2312-0967. Pharmaceutical review. 2016. № 4 
Економіка аптечних і фармацевтичних підприємств

Economics of phapmaceutical structures

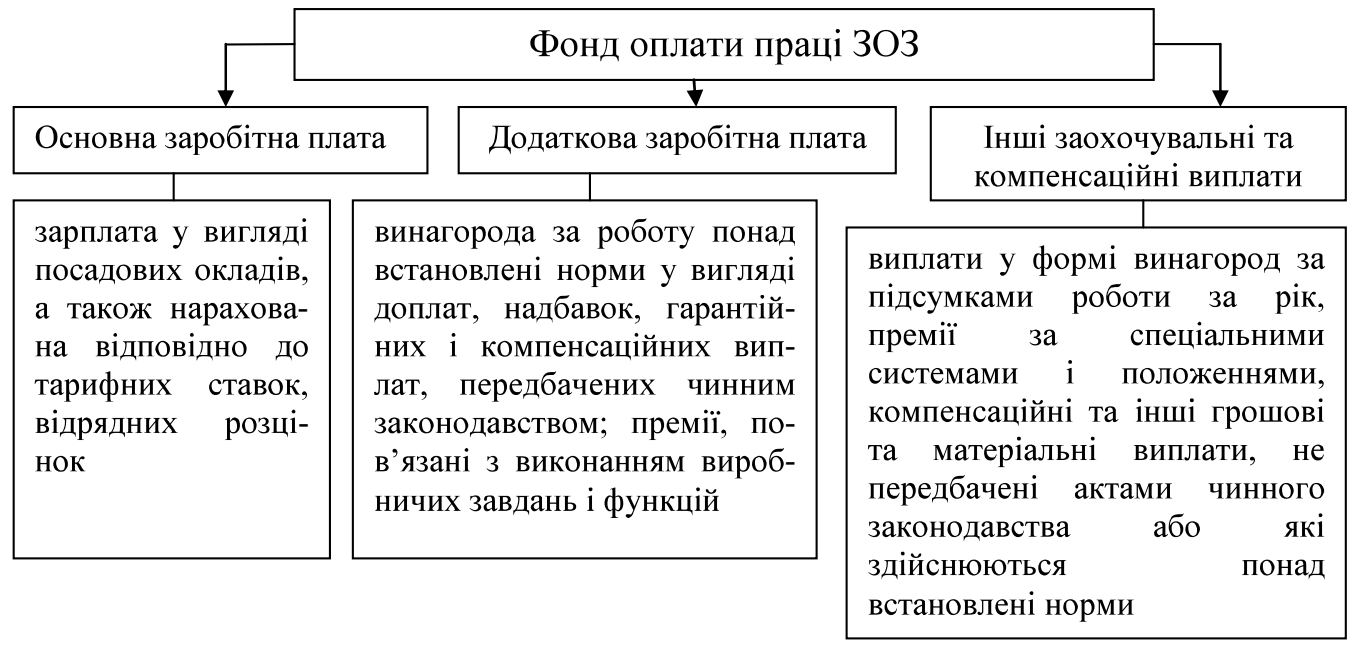

Рис. 2. Структура фонду оплати праці закладу охорони здоров'я (розроблено на підставі [6, 7]).

окладів працівників 303 та установ соціального захисту здійснюється: за наявність кваліфрікаційної категорії, за оперативне втручання, за диплом з відзнакою, за керування санітарним транспортом, у зв'язку зі шкідливими і важкими умовами праці, інші підвищення посадових окладів (тарифрних ставок) [8]. Згідно із Законом України від 24.03.95 р. № 108/95-ВР «Про оплату праці» додаткова заробітна плата - це винагорода за роботу понад встановлені норми, за трудові успіхи, винахідливість і за особливі умови праці [6]. Типову структуру фронду додаткової заробітної плати 303 наведено на рисунку 3.

До складу інших заохочувальних та компенсаційних виплат належать виплати у формі винагород за підсумками роботи за рік, премії за спеціальними системами і положеннями, компенсаційні та інші гро-

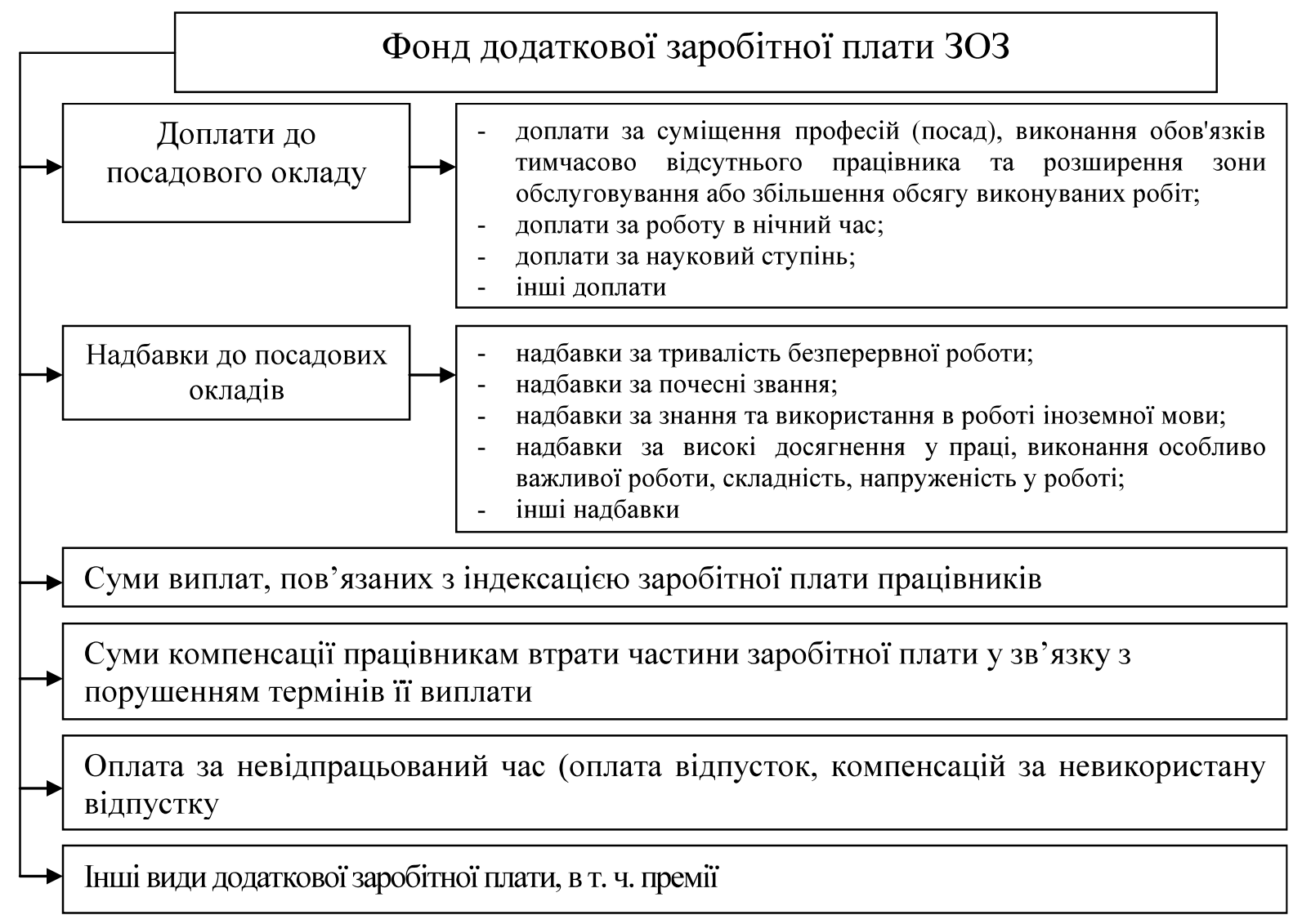

Рис. 3. Структура фронду додаткової заробітної плати 303 (розроблено на підставі [8]).

ISSN 2312-0967. Фармацевтичний часопис. 2016. № 4 
шові та матеріальні виплати, не передбачені актами чинного законодавства або які здійснюються понад встановлені вказаними актами норми [7]. Склад інших заохочувальних та компенсаційних виплат 303 наведено на рисунку 4.

Не належать до фонду оплати праці суми допомоги та інші виплати, що здійснюються за рахунок коштів фрондів державного соціального страхування (допомога 3 тимчасової непрацездатності, у зв'язку 3 вагітністю і пологами, при народженні дитини, на поховання тощо), а також витрати на відрядження, матеріальна допомога разового характеру, що надає установа окремим працівникам у зв'язку із сімейними обставинами, на оплату лікування, оздоровлення дітей, поховання, суми благодійної допомоги та інші виплати, які визначені розділом 3 Інструкції зі статистики заробітної плати [5].

Отже, всі складові фронду оплати праці державного $303 є$ видатками кошторису, які обліковуються за статтею 1110 «Оплата праці працівників бюджетних установ» економічної класифрікації видатків тощо.
Лікарям, які проводять обов'язкові медичні огляди різних категорій працівників (громадян) відповідно до Постанови Кабінету Міністрів України від 17.09.96р. № 1138 «Про затвердження переліку платних послуг, які надаються в державних 303 та вищих медичних закладах освіти», оплата праці здійснюється за рахунок коштів спеціального фонду 303 за фрактично відпрацьований час, виходячи зі встановлених посадових окладів [10].

Окрім бюджетних асигнувань, джерелом фрінансування видатків на оплату праці 303 можуть бути кошти, які надходять від підприємств, організацій, установ за укладеними угодами на проведення медичного обслуговування їх працівників, кошти від надання платних послуг (видача довідок та ін.), надходження від спонсорських і благодійних внесків [2].

Видатки бюджетних медичних 303 поділяють на касові та фрактичні. Касовими видатками вважаються всі виплати, здійснені з реєстраційних рахунків як готівкою, так і шляхом безготівкових переказів. Фактичні видатки - це реальні, кінцеві видатки установи,

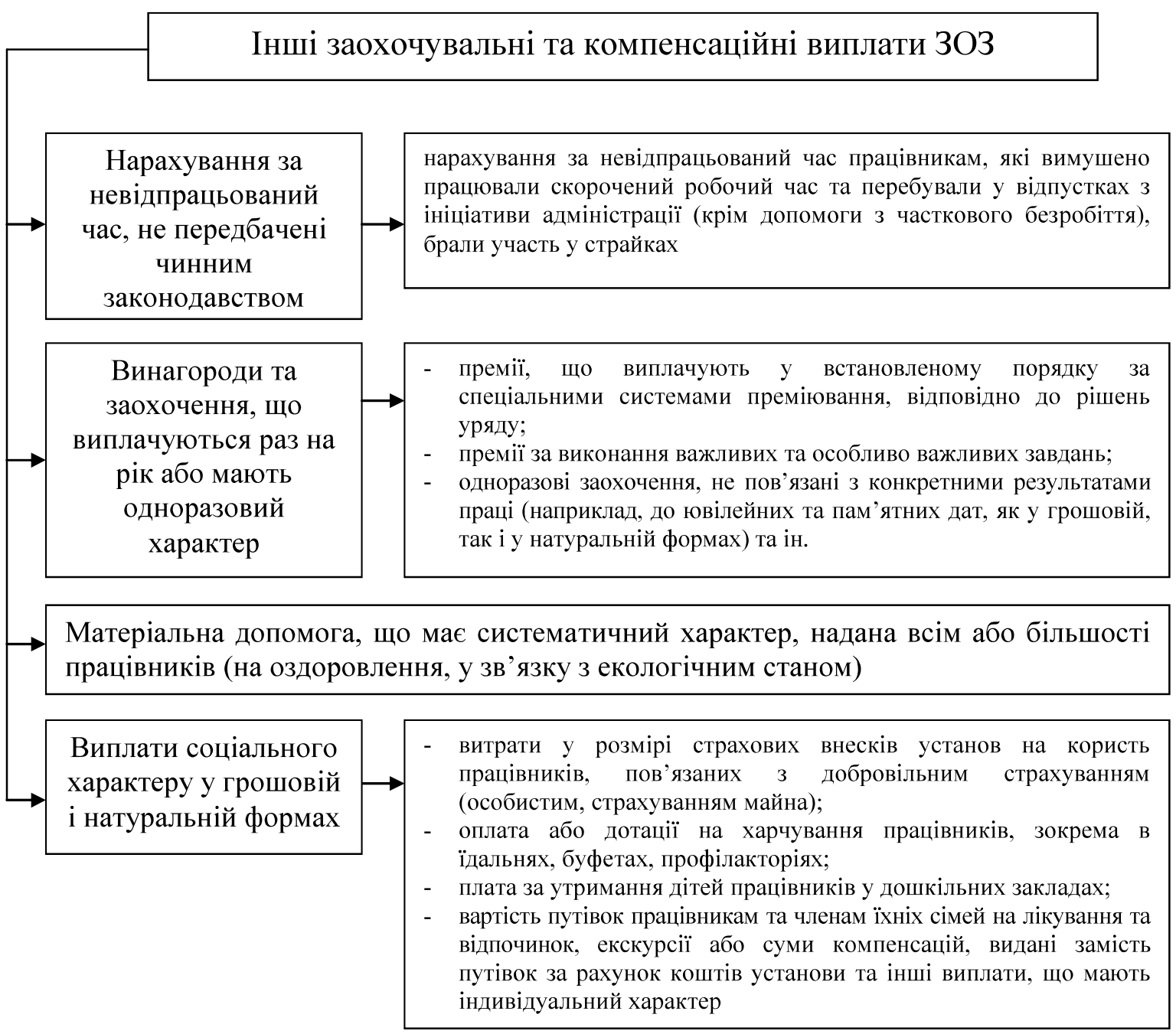

Рис. 4. Структура фонду додаткової заробітної плати 303 (розроблено на підставі [7]).

ISSN 2312-0967. Pharmaceutical review. 2016. № 4 
Економіка аптечних і фармацевтичних підприємств Economics of phapmaceutical structures

оформлені відповідними документами. Відповідно, касові видатки 303 на оплату праці - це кошти, отримані на рахунки установи для виплати заробітної плати та її безпосередня виплата, а фрактичні видатки - це сума фрактично нарахованої заробітної плати.

Облік видатків (в т. ч. на заробітну плату) загального фонду 303 здійснюється на рахунку № 80 «Видатки загального фонду», облік видатків спеціального фронду - на рахунку № 81 «Видатки спеціального фронду», за дебетом яких нараховуються видатки, а за кредитом вони списуються на результат виконання кошторису за загальним або спеціальним фрондом, т. п. на рахунок № 43 «Результат виконання кошторису». Для обліку розрахунків $з$ працівниками за всіма видами заробітної плати і допомоги у зв'язку з тимчасовою непрацездатністю призначено пасивний субрахунок № 661 «Розрахунки із заробітної плати» рахунка № 66 «Розрахунки 3 оплати праці». За кредитом даного субрахунку відображаються нараховані суми, а за дебетом - утримання, вирахування та виплати заробітної плати [4].

Стандартні операції з обліку фактичних видатків 303 на заробітну плату, що здійснюються за рахунок бюджетних коштів. Облік касових видатків у державних 303 ведеться на рахунку 32 «Рахунки в казначействі» у розрізі відповідних субрахунків. За дебетом даного рахунку відображаються суми грошових коштів, які були отримані у вигляді фрінансування, а за кредитом - їх використання [4].

Операції з обліку касових і фрактичних видатків на оплату праці в державних 303 наведені у таблиці 1.

Аналітичний облік за субрахунком № 661 ведеться на картках-довідках фр. № 417, які відкриваються окремо на кожного працівника. В картках-довідках щомісячно реєструються дані про нараховану заробітну плату та утримання за видами. Синтетичний облік видатків на оплату праці здійснюється в Меморіальному ордері № 5 - «Зведення розрахункових відомостей із заробітної плати та стипендії» (форма №405(бюджет)). До меморіального ордера додають всі документи, які є підставою для нарахування заробітної плати [1]. Під кінець місяця підводять підсумки за меморіальним ордером і одержані дані, у вигляді відповідної кореспонденції рахунків, записують до книги «Журнал-головна».

Таблиця 1. Облік касових і фрактичних видатків на заробітну плату в державному 303

\begin{tabular}{|l|c|c|c|c|}
\hline \multirow{2}{*}{ Зміст господарської операції } & \multicolumn{2}{|c|}{ Бухгалтерський запис } & \multicolumn{2}{|c|}{ Код економічної класифрікації видатків } \\
\cline { 2 - 5 } & дебет & кредит & касових & фактичних \\
\hline Нараховано заробітну плату & 80 & 661 & - & 1110 \\
\hline Виплачено заробітну плату & 661 & 32 & 1110 & - \\
\hline
\end{tabular}

Висновки. Таким чином, дана стаття є відображенням традицій у сучасному бухгалтерському обліку в переддень реформування сучасної системи охорони здоров'я України. Наша праця фрактично відображає недоліки та переваги бюджетування у системі М. О. Семашко та може слугувати «дорожньою картою» у реформуванні оплати праці та послуг, що планується в 2017 році МОЗ України. На жаль, ми не можемо сьогодні проводити моделювання фрінансування в галузі охорони здоров'я України оскільки багато юридичних структур у МОЗ України просто не існує або знаходиться на стадії створення. Відповідно, невідома фрінансова логістика пов'язана з оплатою товарів та послуг у сорері охорони здоров'я та орармацевтичної галузі України.

Підсумовуючи результати проведеного дослідження, можна стверджувати, що ефективність системи організації обліку видатків на оплату праці в державних медичних закладах, зокрема у фрармацевтичних підрозділах 303, значною мірою залежить від дотримання норм та положень чинного законодавства щодо праці та її оплати, що потребує постійного доопрацювання в частині матеріального стимулювання працівників медичної та фрармацевтичної сорери, від- повідності рівня заробітної плати медичних та фрармацевтичних працівників 3 рівнем відповідальності за виконання ними функціональних обов'язків.

Згідно з Постановою КМУ від 01.01.2017 р. також запроваджується пілотний Проект щодо нової системи оплати в Донецькій, Черкаській, Полтавській областях та м. Київ. Досконало проаналізувати переваги та недоліки нової системи оплати праці в охороні здоров'я буде надзвичайно важко, оскільки, як було зазначено вище, уже з 01.07.2017p. всі 303 України будуть змушені перейти на нову систему оплати. Порівняння методології оплати праці після вступу у законну силу законопроекту № 2309а від 07.07.2015 р. та зміни системи фрінансування, яка планується 3 1.07.2017 р., є предметом подальших досліджень.

Удосконалення існуючої методики обліку видатків на оплату праці в державних 303 шляхом розробки науково-практичних рекомендацій за даною ділянкою обліку; використання в обліковій практиці відповідної системи рахунків та субрахунків; запровадження в бюджетну сореру національних положень (стандартів) бухгалтерського обліку в державному секторі зумовлює напрямки подальших наукових досліджень.

ISSN 2312-0967. Фармацевтичний часопис. 2016. № 4 


\section{Список літератури}

1. Облік у бюджетних установах / [Ватуля І. Д., Ватуля І. М., Левченко 3. М., Романченко Ю. О. ]. К. : Центр учбової літератури, 2009. - 368 с.

2. Сисюк С. В. Визначення вартості платних медичних послуг та їх облікове забезпечення / С. В. Сисюк, Н. М. Зорій // Вісник Запорізького національного університету. - 2010. - № 2(6), С. 181-186.

3. Фаріон І. Д. Бухгалтерський облік в бюджетних установах: навч. посібн. / І. Д. Фаріон, О. Т. Галько. Тернопіль : Економічна думка, 2008. - 750 с.

4. Черничук Л. В. Облік у бюджетних установах / Л. В. Черничук, М. І. Мниліч. - Чернівці : Книги -XXI, 2007. - 400 с.

5. Шара $€$. Ю. Бухгалтерський облік у бюджетних установах і організаціях : навч. посібн. / Є. Ю. Шара, О. М. Андрієнко, Л. І. Жидеєва. - Київ : Центр учбової літератури, 2011. - 440 с.

6. Закон України «Про оплату праці»: за станом на 24.03.1995 р., № 108/95-ВР із змінами і доповненнями / Верховна Рада України. - Офіц. вид. - К. : Відомості Верховної Ради України, 1995. - № 17.
7. Інструкція зі статистики заробітної плати: за станом на 13.01.2004 р., № 5. / Держкомстат України. - Офріц. вид. - К. : Офріційний вісник України, 2004. - № 4.

8. Наказ «Про впорядкування умов оплати праці працівників закладів охорони здоров'я та установ соціального захисту населення»: за станом на 05.10.2005 р., № 308/519/ Міністерство праці та соціальної політики України, Міністерство охорони здоров'я України. - Офріц. вид. - К. : Офріційний вісник України, 2005. - № 42.

9. Постанова «Про оплату праці працівників на основі Єдиної тарисрної сітки розрядів і коефріцієнтів 3 оплати праці працівників установ, закладів та організацій окремих галузей бюджетної сфрери»: за станом на 30.08.2002 р., № 1298 / Кабінет Міністрів України. Офріц. вид. - К. : Офріційний вісник України, 2002. - № 36.

10. Постанова «Про затвердження переліку платних послуг, які надаються в державних закладах охорони здоров'я та вищих медичних закладах освіти»: за станом на 17.09.96 р., № 1138 / Кабінет Міністрів України. Офріц. вид. - К. : Урядовий кур'єр. - 1996. - 26 вересня.

\title{
МЕТОДОЛОГИЯ ОПЛАТЫ ТРУДА В ГОСУДАРСТВЕННЫХ УЧРЕЖДЕНИЯХ ЗДРАВООХРАНЕНИЯ
}

\section{А. В. Комар, А. М. Кричковская, Н. Л. Заярнюк, А. И. Хоменко, В. П. Новиков}

\author{
Национальный университет «Львовская Политехника», Львов
}

Резюме: исследовано основные аспекты организации учета расходов по оплате труда в государственных учреждениях здравоохранения на основе действующего нормативно-правового обеспечения. Рассмотрено организацию учета расходов медицинского учреждения на основную, дополнительную зарплату и другие компенсационные, поощрительные выплаты в системе счетов бюджетного учета.

Ключевые слова: фонд оплаты труда, кассовые и фактические расходы, расходы по оплате труда, основная и дополнительная зарплата, компенсационные и поощрительные выплаты.

\section{METHODOLOGY OF LABOR REMUNERATION IN PUBLIC HEALTH INSTITUTIONS}

\section{A. V. Komar, A. M. Krychkovska, N. L. Zayarnyuk, A. I. Khomenko, V. P. Novikov}

\section{National University "Lviv Politechnika"}

Summary: the basic aspects of the organization of accounting for labor costs in the public health institutions on the basis of the current regulatory and legal support were studied. We considered an accounting organization of medical institutions in the basic costs, extra salaries and other compensation, incentive payments in the budget accounting system of accounts.

Key words: wages fund, payroll cash and actual costs, labor costs, the main and additional wages, compensation and incentive payments. 